\title{
Time Management as a Predictive Measure of Secondary School Principals' Managerial Effectiveness in Southwest Nigeria
}

\author{
Belo, Fawziyah .A. (Ph.D) \\ Department of Educational Management, Faculty of Education, Ekiti State University, Ado-Ekiti, Nigeria
}

\begin{abstract}
Time is the scarcest resource in the universe in which same amount of it is given to individuals without prejudice to their status. Hence, its utilization determines organizational success or otherwise. As the chief manager of secondary schools, ability of the principal in managing his time as well as that of his teachers and students goes a long way in predicting the success or otherwise of school goals, which could in turn enhance or hinder his managerial effectiveness. This study therefore examined time management as a predictive measure of secondary school principals' managerial effectiveness in Southwest Nigeria. The descriptive research design of the survey type was used for the study. 80, 291 secondary school teachers in Southwest Nigeria were the population for the study. A sample of 2,040 teachers was selected from 102 Secondary Schools in 17 local Government Areas from 3 States in Southwest Nigeria through random, proportionate and stratified sampling techniques. Information was obtained from the sample through the use of a self-developed instrument tagged "The Prediction of time Management on Principals' Managerial Effectiveness Questionnaire". The instrument was validated with a reliability coefficient of 0.85 . The hypothesis was tested with Regression Analysis at 0.05 level of significance. The study revealed that secondary school principals in Southwest Nigeria were effective in time management. Result also suggested that management of teachers' time is the best predictor while management of students' time is the least predictor of principals' managerial effectiveness. Based on the findings, it was concluded that time management, especially teachers' time is a predictor of secondary school principals' managerial effectiveness. Hence, it was recommended that principals should be encouraged to improve upon their managerial effectiveness from being effective to highly effective. It was also recommended that principals should frequently be encouraged by their employer to maintain management of teachers' time in order to continually enhance attainment of school goals.
\end{abstract}

Keywords: Time, Time Management, Principals and Managerial Effectiveness.

DOI: $10.7176 / \mathrm{JEP} / 11-26-14$

Publication date:September $30^{\text {th }} 2020$

\section{Introduction}

The school system like all organizations has set goals and objectives to be achieved at specified period. In secondary school administration, the accomplishment of its goals depend to a very large extent on the ability of the chief administrator or manager who is also referred to as the principal (Belo, 2016). As the institutional head, he occupies a unique and strategic position and as well laden with many responsibilities such as influencing educational improvement, interpreting policies, executing instructional programmes, ensuring proper management of the school as well as encouraging staff development among others. In addition, the school manager as the liaison officer between the government, school and community in which the school is situated interprets government policies and objectives to the school and community and as well feed the government back on the expectations of the school and community. He/she is therefore accountable for progress or otherwise in the school. Myer in Belo (2016) summed it up that the principals' position could be compared to that of a man that lives in a glass house who is not expected to throw stones.

Without being too sentimental, if two or three schools are endowed with the same resources, one may emerge as a better school in terms of its overall performance. The distinguishing factor could be managerial roles. Managerial effectiveness is therefore the glue which binds school administration together and the vehicular means for ensuring attainment of school goals. Olagboye (2004) contended that for any organization to be successful in achieving its objectives in terms of increased productivity, together with workers' commitment, it requires efficient leadership and effective management of people. This indicates that the governance of organizations and possibilities of achieving advantages is a function of factors associated with effective management. In a related development, Olorunsola and Belo (2018) contended that the primary goal of an effective principal should be how to enhance smooth running of the school with emphasis on keeping activities manageable even in the midst of pressure. They concluded that an effective principal will always consider the achievement and happiness of his/her students and members of staff in school governance. Belo (2016) noted that a principal could be adjudged effective if he/she can effectively communicate schools' decisions to members of staff as and when due as well as welcome the opinions of his/her members of staff, motivate members of staff when and where necessary, supervise teachers' activities in order to ensure qualitative instructional deliveries. She added that an effective school manager is the one that ensures teachers' implementation of school curriculum, effective resource management, total compliance 
to school rules and regulations by the teachers and students and as well devise means of sanctioning defaulters, one who delegates responsibilities to competent subordinates for ease of administration in addition to ensuring harmonious teacher-student relationship among others. To achieve these, principals are expected to judiciously manage their time in addition to that of their teachers' and students' time. Personal observation however showed situations where stated goals are not achieved within the stipulated time frame which could be traced to principal's incompetence in time management. Hallinger and Murphy (2013) summed it up that finding time to perform multifarious tasks is one of the greatest challenges of leadership for school improvement in the principals' job.

It is generally believed that time passes in a successive forward movement in accordance with a uniquely controlled system, which can neither be stopped, changed nor turned off or on like machine. Thus, individual's effectiveness is a function of time as being measured in his/her ability to efficiently and effectively manage the available time to him/her. Ojo and Olaniyan (2008) argued that time itself cannot be managed because it is constant and always goes forward and never backward. They explained that everyone has the same amount of time in a day; therefore, if one is managing time, he/she is not trying to manipulate it but trying to make the best use of one's time. In a related development, Belo (2016) added that time is a valuable resource which must be adequately utilized in addition to other resources in educational institutions in order to accomplish stated goals and that whatever the aspirations and achievements of man may be, they have to be achieved with time. It therefore becomes imperative that principals should effectively manage their time as well as that of their teachers and students so as to fast track the accomplishment of goals for which the school stands.

Time management refers to the application of the appropriate skills and abilities required in carrying out right activity at the appropriate time with the intent of achieving set goals. That is, it is the management of one's activities in a bid to ensuring the accomplishment of such activities within the allocated time frame. (Akomolafe, 2011). She equally affirmed that time management is the act of arranging, organizing, scheduling and budgeting one's time for the purpose of generating more effective work and productivity. In his own contribution, Donaldson (2011) affirmed that effective management of time is required for coping with the pressures of modern life without subjecting one to excessive stress. He emphasized that good time management does not mean that managers do more work, it means focusing on the tasks that matter and which will make difference. He thus concluded that the aim of good time management is to achieve the lifestyle balance which administrators need and that good time at work means doing high quality and not high quantity work.

Ekundayo and Kolawole (2013) explained time management as the ability to produce and follow a schedule, meet deadlines, prioritize and minimize distractions and unimportant tasks. Manktelow in Akomolafe (2005) submitted that school administrators' managerial abilities should reflect on their time management skills. He added that they should devote available administrative time to immediate administrative tasks and ability occurrences. He concluded that the heart of time management is concentration on results and not on being busy. It could thus be said that time management entails making use of one's time, so that the person involved can handle all his/her responsibilities, without giving to the misery of procrastination; and since school managers are saddled with the responsibility of ensuring quality and timely delivery of educational services, its achievement therefore depends on the manager's ability to judiciously manage his time as well as that of his teachers and students in addition to other available limited resources.

It is not a gain saying that secondary education is unique in the educational development of a child. Being the link between primary and tertiary education, the knowledge, skills, values and attitudes acquired at this stage will further complement those acquired at the primary level and when these are combined will prepare such child for tertiary education. It could thus be said that in providing an educational climate that will aid attainment of school goals, principals are expected to judiciously manage their time, teachers' and students' time among competing job demands. This might be the reason why Akomolafe (2005) asserted that judicious use of time is an important asset to school organization and that it is very essential to manage activities by following time management principles and skills. She concluded that the absence of personal time management is characterized by last minute rush to meet deadlines and this subsequently leads to managers being double booked or not achieving their set goals. Zucas and David (2012) concluded that since time management cannot be separated from management functions, it therefore becomes one of the effective factors for enhancing managerial effectiveness.

Instances abound where principals, teachers and students are at cross roads due to principals' inability to effectively manage their time as well as that of the teachers and the students. A scenario reveals that some principals do not bother to inform teachers about issues affecting them and the school on time while some care less about their staff welfare in addition to showing lukewarm attitude to teachers' and students' discipline. Some principals also spend much time in attending to visitors and this tend to affect school programmes, some fix staff meetings during long break which extend to subsequent periods and eventually nothing is done for the rest of the day. Also, some principals derive pleasure in having meeting with members of staff after morning devotion, this in some cases tend to affect first period of the school as well as prevent such principal from attending to precious issues waiting for him in the office. Some also involve themselves in routines and details that should have been delegated as well as wasting time with drop-in visitors. In addition to the above, some principals do not pay 
attention to the hours spent on agricultural science practical as well as short and long breaks. Subsequent periods after the practical and breaks could either be wasted by the teachers or the students if the amount of time allocated to each activity is not well managed by the principal. All these are pointers that there could be managerial ineffectiveness if school managers do not make judicious use of their time as well as that of teachers and the students.

Writing on the relevance of time management to principals' managerial effectiveness, Grissom, Loeb and Master (2012) reported that time-use decisions are important for effective leadership as evidenced by the relationship between principal time use and school outcomes. Similarly, Mullins in Akinfolarin (2017) pointed out that whatever the attributes or the qualities of successful managers are, or the qualities of subordinate staff are, one essential underlying criterion is the effective use of time. It could thus be concluded that principals' incompetence in the effective management of time would hinder administrative and managerial efforts and the resultant effect is the non- accomplishment of school goals.

\section{Statement of the Problem}

It has been observed that managerial effectiveness of secondary school principals in southwest Nigeria is jeopardizing. The observed principals' managerial ineffectiveness includes poor supervision of teaching-learning process, inadequate communication skill, unhealthy teacher-student relationship, indiscipline among teachers and students, poor teachers' motivation among others. Critics have attributed the perceived and other principals' managerial ineffectiveness to principals' leadership styles, poor principal-teacher relationship, principals' time management skills among other factors but with little effort on how principals manage their own time, teachers' time as well as the students' time. Premised on this problem, the study therefore investigated whether the perceived low principals' managerial effectiveness could stem from how principals manage their time as well as that of their teachers and the students because the degree of principals' managerial effectiveness and success in achieving school goals could be a product of adequate planning and use of time as a resource, while its mismanagement could lead to managerial ineffectiveness. The problem of the study is therefore the seemingly non clarity of the predictive measure of principals' time, teachers' time and students' time on the managerial effectiveness of secondary school principals in southwest Nigeria. On the basis of the aforementioned problems, a research question was raised thus:

To what extent are secondary school principals in southwest Nigeria effective in school management?

\section{Research Hypothesis}

- Management of principals', teachers' and students' time will not significantly predict principals' managerial effectiveness.

\section{Methodology}

Descriptive research design of the survey type was used in the study. The population of the study comprised 80,291 secondary school teachers in Southwest Nigeria constituted the population for the study. A sample of 2,040 teachers were selected from 17 Local Government Areas in Southwest Nigeria. In doing this, 3 states were randomly selected from the 6 states that constituted southwest Nigeria and this was followed by selecting 17 Local Government Areas using proportionate stratified sampling technique. 6 schools were randomly selected from each of the 17 Local Government Areas making a total of 102 schools. This was followed by the selection of 2,040 teachers using stratified sampling technique at the rate of 20 teachers per school.

A self-designed instrument titled "The Prediction of Time Management on Principals' Managerial Effectiveness Questionnaire', was used for the study. The instrument was validated by experts in Educational Management and Tests and Measurement in the Faculty of Education, Ekiti State University. The reliability of the instrument was established through test-retest method which yielded a coefficient of 0.85 . Data collected for the research question was analysed with frequency count and percentage. The hypothesis was tested with regression analysis at 0.05 level of significance.

\section{Results}

5.1 General Question 1: To what extent are secondary school principals in southwest Nigeria effective in school management? 
Table 1: Principals' Managerial Effectiveness

\begin{tabular}{|c|c|c|c|c|c|c|}
\hline \multirow{2}{*}{$\begin{array}{l}\text { My principal: } \\
\text { ITEMS }\end{array}$} & \multicolumn{2}{|l|}{$\mathrm{HE}$} & \multicolumn{2}{|l|}{$\mathrm{E}$} & \multicolumn{2}{|l|}{$\mathrm{NE}$} \\
\hline & $\mathrm{F}$ & $\%$ & $\mathrm{~F}$ & $\%$ & $\mathrm{~F}$ & $\%$ \\
\hline Facilitates prompt payment of staff salaries & 717 & 35.1 & 936 & 45.9 & 387 & 19.0 \\
\hline Gives personal recognition for work well done & 644 & 31.6 & 870 & 42.6 & 526 & 25.8 \\
\hline Encourages personal development of members of staff & 314 & 39.9 & 854 & 41.9 & 372 & 18.2 \\
\hline Responds to teachers' needs as and when due & 277 & 42.0 & 922 & 45.2 & 241 & 11.8 \\
\hline $\begin{array}{l}\text { Informs members of staff about issues that affect them \& the school } \\
\text { on time }\end{array}$ & 657 & 32.2 & 983 & 48.2 & 400 & 19.6 \\
\hline Listens well to other people's Ideas & 771 & 37.8 & 1029 & 50.4 & 240 & 11.8 \\
\hline imely communication of decisions & 631 & 30.9 & 1246 & 61.1 & 163 & 8.0 \\
\hline Spends sufficient time to attend to students' disciplinary problems & 763 & 37.4 & 1041 & 51.0 & 236 & 11.6 \\
\hline Encourages teachers' regularity in school & 815 & 40.0 & 1017 & 49.9 & 208 & 10.2 \\
\hline Ensures that teachers meet deadline for work schedules. & 823 & 40.3 & 953 & 46.7 & 264 & 12.9 \\
\hline Encourages punishment of misbehaved students. & 642 & 31.5 & 1221 & 59.9 & 177 & 8.7 \\
\hline $\begin{array}{l}\text { Takes necessary disciplinary measures against erring members of } \\
\text { staff. }\end{array}$ & 359 & 17.6 & 1390 & 68.1 & 291 & 14.3 \\
\hline Encourages members of staff to respect students' right in the school & 462 & 22.6 & 1346 & 66.0 & 232 & 11.9 \\
\hline Allows teachers to advice students when necessary & 896 & 43.9 & 1030 & 50.5 & 114 & 5.6 \\
\hline $\begin{array}{l}\text { Ensures that students' records kept by teachers are honest \& } \\
\text { representation of facts }\end{array}$ & 777 & 38.1 & 1132 & 55.5 & 131 & 6.4 \\
\hline Frowns at unhealthy relationship between teachers and students & 905 & 44.4 & 977 & 47.9 & 158 & 7.7 \\
\hline es teachers during teaching - learning & 786 & 38.5 & 1104 & 54.1 & 150 & 7.4 \\
\hline Regularly supervise teachers' lesson notes & 631 & 30.1 & 960 & 47.1 & 449 & 22.0 \\
\hline Encourages participatory supervisory system. & 688 & 33.7 & 1063 & 52.1 & 289 & 14.2 \\
\hline Total Average & $\begin{array}{l}34.9 \\
=35\end{array}$ & & $\begin{array}{l}51.5 \\
=52\end{array}$ & & $13 \%$ & \\
\hline
\end{tabular}

Table 1 shows that $35 \%$ of the respondents agreed that principals were highly effective in school management while $52 \%$ attested to principals' effectiveness and $13 \%$ attested to principals' ineffectiveness in school management.

5.2 Hypothesis 1: Management of principals', teachers' and students' time will not significantly predict principals' managerial effectiveness

Table 2: Multiple Regression Analysis showing contribution of principals', teachers' and students' time management to principals' managerial effectiveness

\begin{tabular}{|c|c|c|c|c|c|c|c|c|}
\hline Variables & B & Std error & Beta & $\mathrm{T}$ & Sig. & $\mathrm{R}$ & $\mathrm{R}^{2}$ & $\mathrm{~F}$ \\
\hline Principals' time & 0.170 & 0.052 & 0.066 & 3.293 & 0.000 & \multirow[b]{3}{*}{0.639} & \multirow[b]{3}{*}{0.407} & \multirow[b]{3}{*}{175.613} \\
\hline Teachers' time & 1.217 & 0.110 & 0.207 & 11.105 & 0.000 & & & \\
\hline Students' time & 0.165 & 0.055 & 0.060 & 3.028 & 0.000 & & & \\
\hline
\end{tabular}

Table 2 shows that principals' teachers' and students' time management jointly and significantly contribute to principals' managerial effectiveness $(\mathrm{F}=175.613, \mathrm{P}<0.05)$. The null hypothesis was therefore rejected. The table reveals that management of teachers' time with a beta weight of 0.207 is the best predictor of principals' managerial effectiveness while management of students' time with a beta weight of 0.060 is the least predictor of secondary school principals' managerial effectiveness in Southwest Nigeria.

\section{Discussion}

The study revealed that secondary school principals in Southwest Nigeria are effective in time management. This implies that judicious management of principals' time, teachers' time and students' time would facilitate the accomplishment of school goals. Probable reason for this might be because principals are more conscious of the fact that they have limited time to attend to many issues if school goals are to be achieved. This finding is in line with Zucas and David (2012) who reported that effective time management which cannot be separated from management functions is a prerequisite for accomplishing organizational objectives.

The study showed that management of teachers' time with a beta weight of 0.207 best predicts the managerial effectiveness of secondary school principals in Southwest Nigeria while management of students' time with a beta weight of 0.60 is the least predictor. This implies that principals who adequately manage time, especially teachers' time since they are the one having regular contact with the students tow towards achieving school goals than their counterparts that are not keen in managing their teachers' time. Reason for this might not be unconnected with the fact that teachers are the hub of educational activities, hence, effective management of their time enhance 
principals' managerial effectiveness. Considering the importance of time management, principals may not achieve managerial success if he/she does not effectively manage his/her teachers' time.

\section{Conclusion}

On the basis of the findings of this study, it was concluded that time management most especially that of teachers is a sine qua non for principals' managerial effectiveness. The study confirmed that principals who effectively manage teachers' time towed towards the path of attaining stated school goals.

\section{Recommendations}

The following recommendations were made on the basis of the findings and conclusion of the study:

1. In-service training and conferences should be regularly organized for secondary school managers in order to keep on reminding them on the need to improve upon their managerial effectiveness from being effective to highly effective.

2. Principals should frequently be encouraged by their employer to maintain management of teachers' time in order to continually enhance attainment of school goals.

3. Principals' knowledge need to be updated on the need to effectively manage their time and that of the students.

\section{References}

Akinfolarin, A.V. (2017). Time Management Strategies as a Panacea for Principals' Administrative Effectiveness in Secondary Schools in Enugu State, Nigeria Journal for studies in Management and Planning. 3(9): 22-31

Akomolafe, C.O. (2005). Principals' Time Management Abilities in Secondary Schools in Nigeria. Nigerian Journal of Educational Administration and Planning 5(1): 59 - 62.

Akomolafe, C.O. (2011). Time Resource Management: Management of Higher Education in Africa. Uyo, Nigeria: Abaam Publishing Co.

Belo, F. A. (2016). Gender- Related Variables and Time Management as Determinants of Secondary School Principals' Managerial Effectiveness in Southwest Nigeria. Unpublished Ph. D Thesis. Ekiti State University, Ado-Ekiti, Nigeria.

Donaldson, M. (2011). "Principals' Approaches to Developing Teacher Quality”. Washington DC: Centre for American Progress.

Ekundayo, H.T \& Kolawole, E.O. (2013). Time Management skills and Administrative Effectiveness of principals in Nigerian Secondary Schools. Journal of Educational and Developmental Psychology. 3(1):133-139.

Hallinger, P. \& Murphy, J.F. (2013). Running on empty? Finding the time and Capacity to Lead Learning. NASSP Bulleting, 97 (1) 5-12.

Ojo, L.B. \& Olaniyan, D.A. (2008). Effective Time Management in Organizations: Panacea or Placebo? European Journal of Scientific Research, 24(1): 130 - 133.

Olagboye, A.A. (2004). School Management and Administration. Ibadan: DailyGraphics Nigeria Ltd.

Olorunsola, E.O \& Belo, F.A. (2018). Administrative challenges and principals' managerial effectiveness in Ogun State public secondary schools. International Journal of Educational Administration and Policy Studies. 10(5): 48-56.

Zucas, M.T. \& David, O.A. (2012). Definition of Time Management. http://www.freetimemanagement.tips.com/d.. 